乳用哺乳子牛におけるホルムアルデヒド中毒の 1 例

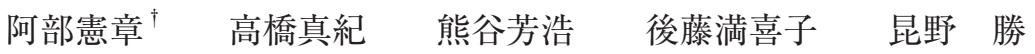 \\ 岩手県県南家畜保健衛生所（† 023-0003 奥州市水沢区佐倉河字東舘 41-1）
}

(2013 年 7 月 24 日受付 $\cdot 2013$ 年 10 月 22 日受理)

要 約

岩手県内の 1 酪農場で, 前日までと異なる発䤉乳が給与された哺乳牛 10 頭中 9 頭が虚脱及び呼吸速迫を示して急死し た．病牛 2 頭の第四胃と近位十二指腸に出血を伴う壊死性炎が観察され，同牛の第四胃内容並びに哺乳牛に与えた発酵 乳からホルムアルデヒドが検出された．ホルムアルデヒドの代謝産物とみなされるギ酸が病牛 4 頭の血清から検出され， 同濃度は $8.5 \sim 42.6 \mathrm{mg} / l$ であった。 得られた成績から, 本事例をホルムアルデヒド中毒と診断し, 同化学物質が混入 した発酵乳を中毒の原因と特定した。——ーワード：ホルムアルデヒド中毒, ホルマリン㠌取, 哺乳子牛.

日獣会誌 $67,129 \sim 133(2014)$

ホルムアルデヒドは無色透明で刺激性を有する水溶性 の気体であり，ホルムアルデヒドを約 $40 \%$ 含有する水 溶液がホルマリンと呼ばれる $[1,2]$. ホルマリンは器具 や室内の消毒薬として用いられ [3], 酪農場では蹄病予 防を目的に蹄浴漕での使用が推奨されている [4]. 海外 では, 防腐効果を期待して, 子牛へ給与する初乳や家畜 飼料穀物に添加されている $[5]$.

ホルマリンは経口摂取，ガスの吸入，皮膚への接触に より毒性を示し，接触部に組織傷害と炎症を引き起こす とともに体内に容易に吸収される $[2]$ ，ホルマリンを誤 飲した人の中毒例では, 消化器粘膜の腐食性変化に加え て，体内に吸収されたホルムアルデヒドの代謝産物に起 因するアシドーシスがみられ $[1,6]$, 後者に関連する循 環障害や中枢神経系障害などの諸症状 [7] を伴う。

ホルマリンの誤飲による家畜の中毒は牛でいくつか報 告されており，原因として蹄浴漕の溶液 [8] やミルク [9] がある. 多量のホルマリンを含むミルクを摂取した 子牛は胃腸炎を引き起こして急死し, 流涎, 腹痛, 下 痢, 眼窩の陥凹, 呼吸困難の諸症状を示す $[5,9]$.

国内において牛のホルムアルデヒド中毒の発生報告は 著者らが知るかぎりみあたらない。この報告では，ホル マリンの誤飲によるホルムアルデヒド中毒と診断した乳 用哺乳子牛の検査成績を述べ, その病理発生を考察し た.

\section{材 料 及 び方 法}

2012 年 3 月 28 日, 乳用成雌牛 130 頭と子牛 20 頭を飼 養する酪農場で，発酵乳を人工的に与えられていた 10 頭中 9 頭が虚脱して起立不能に陥った. 病牛は呼吸速迫, 知覚の鈍麻，眼窩の陥凹及び流涎を伴い，すべてが発病 後 12 時間以内に死亡した。

当農場では 7 ～ 60 日齢の子牛に発酵乳を給与し，1 日 1 頭あたり最大 $3.6 l$ を朝，昼，晚の 3 回に分けて与えて いた。本病発生日は, 発酵乳を調整している容器を新た に開封し，同じ容器内の発酵乳を朝と昼に与えた。同日 の 1 頭あたりの推定給与量は，発病した 9 頭では 1.2 $2.4 l$, 未発病であり離乳間近の 1 頭では $0.5 l$ と算定され た。

発酵乳の調整方法について調査するとともに，発酵乳 を給与された $8 〜 49$ 日齢の子牛 6 頭（死亡牛 1 頭：No 1 , 瀕死期の病牛 4 頭 : Nos. $2 \sim 5$, 未発病牛 1 頭 : No. 6), $75 \sim 91$ 日歯令で離乳後の同居牛 4 頭（Nos. 7 ～10) の合計 10 頭並びに子牛に与えた発酵乳を以下のように 検索した.

病理学的検査：病牛 2 頭（Nos. 1, 2) の剖検を行い, 全身諸組織から得た検査材料を $10 \%$ 緩衝ホルマリン液 で固定してパラフィン包埋後薄切し，ヘマトキシリン・ エオジン（HE）染色を施して鏡検した. 1頭（No. 2) は死亡直後に剖検に供した。

血液生化学的検査：病牛 4 頭 $(\operatorname{Nos} .2 \sim 5)$, 未発病

$\dagger$ 連絡責任者：阿部憲章（岩手県県南家畜保健衛生所） 023-0003 奥州市水沢区佐倉河字東舘 41-1

ช0197-23-3531 FAX 0197-23-3593

E-mail : noriaki-abe@pref.iwate.jp 


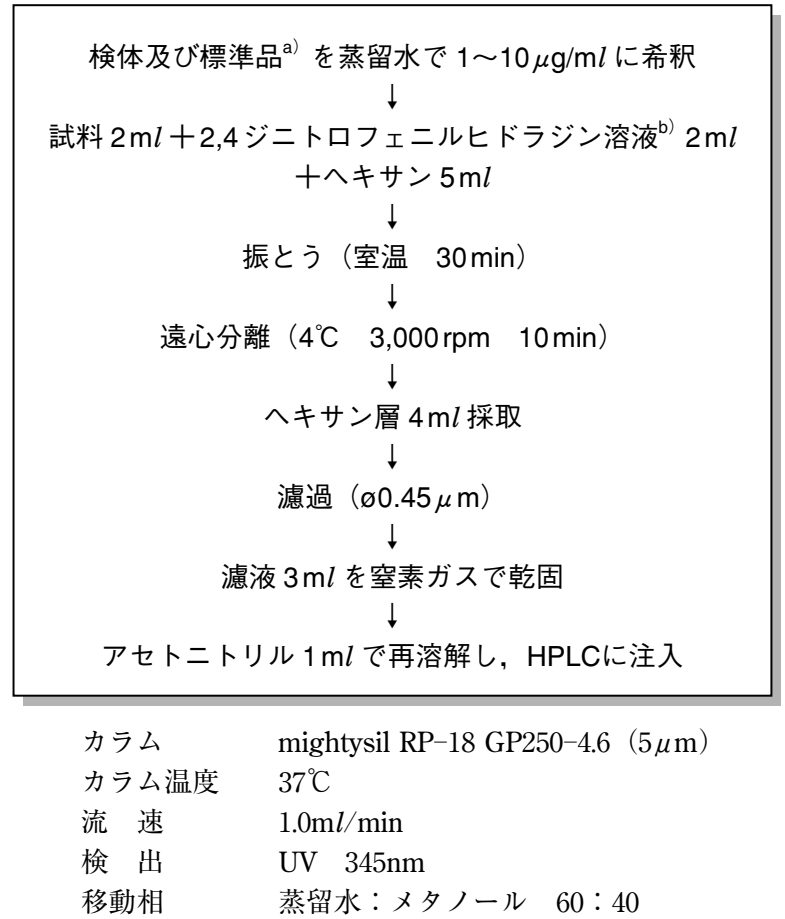

図 1 ホルムアルデヒドの抽出法及びHPLC の条件

a）ホルムアルデヒド標準液 $1,000 \mathrm{mg} / l$ （関東化学, 東京）

b) $\mathrm{DNPH}$ (関東化学, 東京) $1.4 \mathrm{~g} / 2 \mathrm{~N}$ 塩酸 $100 \mathrm{~m} l$

牛（No.6）及び同居牛 4 頭から発病日に採取した血液 を材料とした。病牛と未発病牛の血液はすべて発酵乳給 与後に採取し, 病牛 4 頭（Nos. 2〜5）からは瀕死期に 採取した. 赤血球数 (RBC), 赤血球容積比 $(\mathrm{Ht})$, へモ グロビン量（Hb）及び白血球数（WBC）を常法に従い 測定した。血清は採取後速やかに分離し，以下の検査時 までー $20{ }^{\circ} \mathrm{C} て ゙$ 保存した. 血清中の総蛋白 (TP), 総コレ ステロール $(\mathrm{TCHO})$, アスパラギン酸アミノトランス

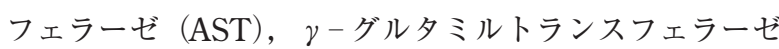
(GGT)，クレアチンホスホキナーゼ $(\mathrm{CK})$ ，血液尿素態 窒素 (BUN), クレアチニン (Cre), ナトリウム $(\mathrm{Na})$, カリウム $(\mathrm{K})$ ，クロール $(\mathrm{Cl})$ をドライケミストリー法 (富士ドライケム $3500 \mathrm{~V}$, 富士フイルムメディカル(株), 東京)，ギ酸及び乳酸を酵素法（Fキット，(株) J.K.イン ターナショナル，東京）により分析した。

ホルムアルデヒドの検出：子牛に与えた発酵乳，剖検 牛 2 頭の第四胃内容, 並びに剖検牛 (No. 2), 未発病牛 (No. 6)，同居牛 4 頭の血清を材料とし, Kaminskiら [10］の方法に従い, 高速液体クロマトグラフィー (HPLC, LaChrom L-7420, (株)日立ハイテクフィールデ イング，東京）を用いて測定した。抽出法及びHPLCの 条件は図 1 のとおりとした。発酵乳と剖検牛の第四胃内 容については, 小型反射式光度計（RQフレックスプラ スメルク(株)，東京）を用いた測定も行った。

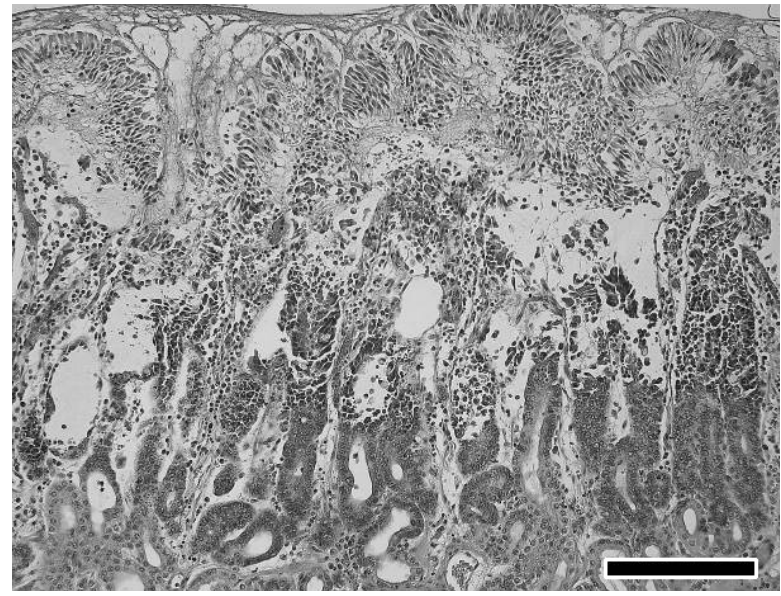

図 2 第四胃 粘膜表層は凝固壊死して剝離し, 拡張した腺腔内に 細胞頽廃物が存在する. 残存する固有層にうっ血及び 細胞浸潤がみられる。(HE染色 $\quad$ B ar $=200 \mu \mathrm{m})$

細菌学的検査：剖検牛 2 頭の肝臓，脾臓，腎臓，心臓， 肺及び脳を, $37^{\circ} \mathrm{C}$ の好気性及び嫌気性下で 48 時間培養 した。好気性培養には $5 \%$ 羊血液加及び DHL 寒天培地 を，嫌気性培養には $5 \%$ 卵黄加 GAM 寒天培地を用い, 後者はガスパック法で培養した。

\section{成 績}

発酵乳の調整方法：発生農場では，成牛の蹄浴資材に ホルマリンを用い，ホルマリンの空き容器を洗浄して発 酵乳の調整容器に使用していた。ホルマリンが入った容 器と使用後の空き容器は別々の場所に保管されていた が，まれに隣り合った場所に置かれていることもあっ た. 発酵乳の調整作業には複数の管理者が従事し, 空き 容器の洗浄, 容器への原乳の投入, 原乳への生菌剂の添 加及び発酵状況の確認の作業担当は特定されていなかっ た.

本病発生日に実施した聞き取り調査により，発生日に 与えた発酵乳の調整開始時期にあたる $2 \sim 3$ 週間前に， ホルマリンが入った容器が置き場所から消えていた事実 が確認された。同日, 当家畜保健衛生所の獣医師が発酵 乳の官能検査を実施し，ホルマリン様の臭気を確認し た。

病理学的検査成績：剖検牛 2 頭の肉眼病変は消化管に 限局し，第四胃と近位十二指腸において顕著に認められ た．粘膜は水腫性に肥厚してうっ血及び出血を伴い，白 色の浸出物を伴う多量の粘液により覆われていた．第四 胃内に残存した凝固乳は前述の白色粘液を混じ，ホルマ リン様の臭気を呈した。

組織学的に主要な病変は第四胃及び十二指腸に存在 し, 出血を伴う壊死性炎が観察された. 粘膜の上皮細胞 層と直下の固有層の表層は層状ないし巣状に凝固壊死し 
からも，病牛の摂取量が急性中毒を起こし得る致死量を 超えていたことが示唆された.

ホルムアルデヒドの代謝経路は実験動物及び人におい て同様であり，体内で産生あるいは体外から摂取された ホルムアルデヒドは，さまざまな組織や細胞においてギ 酸に急速に酸化されて最終的に水と二酸化炭素に分解さ れる [1]. 血液中においてもホルムアルデヒドの代謝は 速やかに行われ，同物質を静脈内投与されたサルやホル マリンを䛊飲した人の中毒例の血液中では，ホルムアル デヒド濃度が速やかに低下し，ギ酸塩やギ酸の濃度が増 加することが報告されている $[6,12-14]$.

ホルムアルデヒド及びギ酸が病牛の血清から検出さ れ，それらの濃度はそれぞれ $0.45 \mu \mathrm{g} / \mathrm{m} l$ 及び 8.5 $42.6 \mathrm{mg} / l$ の範囲を示し, 未発病牛や同居牛の血清から は検出されなかった．分析法は異なるものの，検出され たホルムアルデヒド濃度は, ホルマリンを含まない飼料 を与えた健康な子牛 [15］の血中濃度（平均 0.512 $\mu \mathrm{g} / \mathrm{g}$ ）と同程度であり，過去に子牛の急性中毒例 [9] で報告された值 $(20 \sim 40 \mu \mathrm{g} / \mathrm{m} l)$ に比較して低い值を 示した. 以上の事実から, 病牛の血液中においてホルム アルデヒドが急速に酸化されて代謝産物であるギ酸の濃 度が増加したことが推察され，人の中毒例 $[6,13,14]$ で示されているように代謝性アシドーシスの病態であっ た可能性が疑われた。

生体内の酸塩基平衡を維持する緩衝調節機構の一つと して細胞内外のイオン交換作用があり，アシドーシスの 病態では細胞内から $\mathrm{K}^{+}$が放出されて高 $\mathrm{K}$ 血症となる [16]。病牛に認められた血清 $\mathrm{K}$ の高值は，血清ギ酸濃度 の増加に関連したと考えられた。同牛には高度な脱水を 示唆する血液所見もみられたことから，血液濃縮の影響 も考慮する必要があるが $[16]$ ，血清 $\mathrm{Na}$ 及び $\mathrm{Cl}$ の值に 増加はみられず，影響の程度は低いと思われた。

病牛の血清ホルムアルデヒド濃度が既報の中毒例に比 ベて低かった正確な理由は不明であるが，ホルムアルデ ヒドが血液中で速やかに代謝される事実から $[1,6$, 12-14]，ホルムアルデヒド摂取から採血までの時間が 影響した可能性が考えられた。ホルムアルデヒド中毒を 疑う事例を診断する際は，血清ギ酸濃度をあわせて測定 することが必要と考えられた。

ホルマリンには，ホルムアルデヒドの重合を避ける目 的で, $15 \%$ 未満のメタノールが加えられていることか ら $[1,2]$, メ夕ノールによる毒性も考慮する必要がある [1].メタノールは体内でホルムアルデヒドに酸化され た後，同様の代謝機序によりギ酸に酸化されて毒性を発 現する $[1,12,17]$. 本事例においても，メタノールの 代謝産物が臨床症状を憎悪した可能性が疑われたが, メ タノールのホルマリン含有量や, 経口摂取後の血液吸収 割合が低い事実から [17]，その程度は軽微であったと
思われた。

ホルムアルデヒドによる消化管障害の程度は, 同化学 物質との接触時間に比例し, 人では重篤な病変が胃に主 座する $[1,6,13]$. 検索牛の主要な消化管病変は化学物 質による急性期病変の特徴を有し [18], 第四胃と近位 十二指腸に限局していた。この病変分布は既報の子牛の 中毒例と一致し [9], 新生子牛の未発達な反鴷胃構造と 関連すると考えられた [19]。すなわち，飲用後の発酵 乳が第二胃溝を経て第四胃に直接流入した結果と推察さ れた。

ホルマリンの誤飲が疑われた本事例では，ホルムアル デヒドの測定に小型反射式光度計を用いた検査手法を活 用し，簡易な手技で迅速に成績が得られた。本検査手法 の成績のみからホルムアルデヒド中毒を診断することは できないものの, HPLCを含む精密機器を保有しない施 設での簡易診断に有用な手法であると思われた。

酪農場におけるフリーストールの普及に伴い，蹄病予 防にホルマリンを使用する農場が増加するものと懸念さ れる。蹄浴漕のホルマリン溶液を牛が誤飲することを防 止するとともに, 同溶液が牛に与える飼料やミルクに混 入することを防ぐ適正な管理について啓発する必要があ る.

\section{引用 文 献}

[1] Pandey CK, Agarwal A, Baronia A, Singh N : Toxicity of ingested formalin and its management, Hum Exp Toxicol, 19, 360-366 (2000)

[2] 森本兼暴: ホルムアルデヒド, 産業中毒便覧, 後藤 稠 編, 1089-1090, 医歯薬出版, 東京 (1977)

[3] 小林晴男, 湯山 章: 消毒薬, 改訂獣医薬理学, 柳谷岩雄 編，258-263，文永堂出版，東京 (1992)

[4] Raven ET : 蹄浴, 牛のフットケアと削蹄, 幡谷正明監 訳, 107-113, チクサン出版社, 東京 (1990)

[5 ] Radostits OM, Gay CC, Hinchcliff KW, Constable PD : Miscellaneous farm chemicals, Veterinary Medicine, A textbook of the diseases of cattle, horses, sheep, pigs and goats, Radostits OM, et al eds, 10th ed, 1846, Saunders Elsevier, Philadelphia (2007)

[6 ] Koppel C, Baudisch H, Schneider V, Ibe K : Suicidal ingestion of formalin with fatal complications, Intens Care Med, 16, 212-214 (1990)

[7] Lim S : Metabolic acidosis, Acta Med Indones, 39, 145-150 (2007)

[8] Mitchell GB, Law JM : Formaldehyde poisoning in cattle, Vet Rec, 115, 283-284 (1984)

[9] Egyed MN, Nobel TA, Shlosberg A, Perl S, Yakobson B, Klopfer U, Neria A : Acute formalin poisoning in calves, Refuah Vet, 38, 31-35 (1981)

[10] Kaminski J, Atwal AS, Mahadevan S : Determination of formaldehyde in fresh and retail milk by liquid column chromatography, J Assoc Off Ana Chem Int, 76, 1010-1013 (1993)

[11] Smyth HF Jr, Seaton J, Fischer L : The single dose 
toxicity of some glycols and derivatives, J Ind Hyg Toxicol, 23, 259-268 (1941)

[12] McMartin KE, Martin-Amat G, Noker PE, Tephly TR : Lack of a role for formaldehyde in methanol poisoning in the monkey, Biochem Pharmacol, 28, 645-649 (1979)

[13] Burkhart KK, Kulig KW, McMartin KE : Formate levels following a formalin ingestion, Vet Hum Toxicol, 32, 135-137 (1990)

[14] Eells JT, McMartin KE, Black K, Virayotha V, Tisdell RH, Tephly TR : Formaldehyde poisoning. Rapid metabolism to formic acid, J Am Med Assoc, 246, 1237-1238 (1981)

[15] Buckley KE, Fisher LJ, MacKay VG : Levels of formaldehyde in milk, blood, and tissues of dairy cows and calves consuming formalin-treated whey, J Agr Food Chem, 36, 1146-1150 (1988)

［16］河合 忠：血清電解質と血液ガス検査，異常值の出るメ カニズム，河合 忠他編，第5版，205-239，医学書院， 東京 (2008)

[17] Von Burg R : Methanol, J Appl Toxicol, 14, 309-313 (1994)

[18] Loeb PM, Eisenstein AM : Caustic injury to the upper gastrointestinal tract, Sleisenger and Fordtran's gastrointestinal and liver disease: Pathophysiology, diagnosis, management, Feldman M, et al. eds, 335342, Saunders, Philadelphia (1998)

[19］岡本全弘：子牛の栄養と代謝，子牛の科学，日本家畜臨 床感染症研究会編，124-130，チクサン出版社，東京 (2009)

\title{
A Case of Formaldehyde Poisoning in Dairy Suckling Calves \\ Noriaki $\mathrm{ABE}^{\dagger}$, Maki TAKAHASHI, Yoshihiro KUMAGAI, Makiko GOTOU and Masaru KONNO
}

\begin{abstract}
* Iwate Prefecture Southern Regional Livestock Hygiene Service Center, 41-1 Higashidate,
\end{abstract} Sakurakawa, Mizusawa-ku, Oushu, 020-0003, Japan

\section{SUMMARY}

On a dairy farm in Iwate Prefecture, nine out of 10 suckling calves died within one day, demonstrating collapse and tachypnea. The fermented milk for these suckling calves was found to be different than the milk they had been given on previous days. Histologically, a necrotic inflammation with hemorrhage was found in the abomasum and proximal duodenum of two of the affected calves. Formaldehyde was identified in the abomasum contents of those calves as well as the fermented milk given to the calves. Formic acid, which is considered to be a formaldehyde metabolite, was detected in the sera of 4 of the affected calves, with a concentration ranging from 8.5 to $42.6 \mathrm{mg} / l$. Based on these results, the disease was diagnosed as poisoning caused by formaldehyde, and the source of the poisoning was its presence in the fermented milk.

- Key words : formaldehyde poisoning, formalin ingestion, suckling calf.

$\dagger$ Correspondence to : Noriaki ABE (Iwate Prefecture Southern Regional Livestock Hygiene Service Center)

41-1 Higashidate, Sakurakawa, Mizusawa-ku, Oushu, 020-0003, Japan

TEL 0197-23-3531 FAX 0197-23-3593 E-mail : noriaki-abe@pref.iwate.jp

J. Jpn. Vet. Med. Assoc., 67, 129 $133(2014)$ 